\title{
System electro-neutralizer of agrochemicals contained in food and water samples through electrons trap
}

\author{
Charles Adriano DUVOISIN ${ }^{1,2 \star}$ (D), José Paulo Felipe Afonso de SOUSA ${ }^{1}$, André Pscheidt ${ }^{3}$, Dilmar BARETTA³, \\ Diogo José HORST ${ }^{2}$, Rogério de Almeida VIEIRA ${ }^{2}$, Carlos Alberto MOURÃO JR. ${ }^{4}$, Mario Alberto SECCHI ${ }^{5}$
}

\begin{abstract}
This study presents a system to electro-neutralize agrochemicals in food and water samples based on the properties of a controlled electron trap, the related apparatus is protected under patent application (WO/2018/090110; INPI: BR 102016 0268486) / (PCT / BR 2017/050115). The efficacy of the system was verified as to the type, quantity, surface tension charge, temperature, $\mathrm{pH}$ and static energy loading of the electrolyte for both solid and liquid samples. It also took into consideration the retention and accumulation measurement of electric charges, verification of electrical potential differences and also accumulation by applying pulsed high voltage in according to the Daniell Cell method. The proposed technology is able to provide the electron-neutralization of acidic and alkaline chemicals and their toxic byproducts by modifying the $\mathrm{pH}$ of the liquid or solid medium. This is justified by the action of the electron trap using different polarities and electrodes in the range of 8 to $100 \mathrm{kV}$.
\end{abstract}

Keywords: agrochemicals; electrolysis; food security; neutralization; toxicity.

Practical Application: One of major concerns of contemporary food security is the enormous amount of pesticides retained in foods and water consumed worldwide. Focused on this serious problem, we are achieving fantastic and very promising results, through a patented electroneutralizer system and method to neutralize pesticides in foods and water. The advantage of the apparatus is its technological ability to electroneutralize pesticides in samples, through electron trap effects, as preliminary results all the toxic gradients contained in both external and internal parts of the foods are purified, without changing their organoleptic properties in a quick, safe with low operational cost process. Thus, this technology practically provides the development of a new appliance or industrial equipment with food purification capability.

\section{Introduction}

Brazil is a major worldwide consumer of food containing agrochemicals. According to the National Cancer Institute (INCA), the Brazilian Association of Collective Health (Abrasco), and the Oswaldo Cruz Foundation (Fiocruz) data on the consumption of such substances are worrisome (Agência Nacional de Vigilância Sanitária, 2014, 2018; Associação Paranaense das Vitimas Expostas ao Amianto e aos Agrotóxicos, 2018; Bassil et al., 2007; Bastos et al., 2011; Belmonte, 2018; Carneiro et al., 2015; Associação Brasileira de Saúde Coletiva, 2018; Duvoisin, 2016; Eustachewich, 2018; Food and Drug Administration, 2011; Instituto Nacional de Câncer, 2010, 2018; Jardim et al., 2009; Magalhães et al., 2018; Masur, 2018; Mourão \& Marques Abramov, 2013; Oliveira et al., 2016; Peres et al., 2005; Rosalles, 2017; Rossi, 2015; Scientific American Brasil, 2016; Sperb, 2016; Velleda, 2017; World Health Organization, 2016, 2018).

The use of agrochemicals tends to increase around the world, since the viability and productive security of agriculture are still based on the productive benefits that modern agrochemicals provide. Given the lack of control over the use of toxic chemicals and the general population's lack of awareness as to health risks due to hazards involved, human poisoning rates are estimated to be high in Brazil. It should be taken into account that according to the World Health Organization (WHO) for each reported case of intoxication there would be 50 non-notified others. There are few ways of neutralizing and removing agrochemicals from food and water before consume their consumption. Some of them consist in using potassium or sodium bicarbonate in alkaline solution in order to neutralize acidic pesticides (90\% of the most used) and also using acetic acid (vinegar) to neutralize the alkaline pesticides (Carneiro et al., 2015; Associação Brasileira de Saúde Coletiva, 2018; World Health Organization, 2018).

However, even by peeling food containing agrochemicals, it can be argued that some chemicals and its residues remain in internal parts of fruits and vegetables, being not completely neutralized or removed. In addition, other particles also remain dispersed in water (Belmonte, 2018). Global consumers are directly intoxicated by the intake of food and water contaminated by agrochemicals and in the medium term this problem will continue. So the need for a system and method for solving this food toxicity issue would be very welcome for everyone. In this

Received 21 Dec., 2018

Accepted 05 May, 2019

${ }^{1}$ Departamento de Ciências da Vida, Universidade de Coimbra, Coimbra, Portugal

${ }^{2}$ Departamento de Química, Universidade Federal de São Paulo, Diadema, SP, Brasil

${ }^{3}$ Programa de Mestrado e Doutorado em Ciências do Solo, Universidade do Estado de Santa Catarina, Lages, SC, Brasil

${ }^{4}$ Departamento de Biofísica e Fisiologia, Universidade Federal de Juiz de Fora, Juiz de Fora, MG, Brasil

${ }^{5}$ Departamento de Ciencias de la Salud, Rosario, Instituto Universitario Italiano de Rosario, Argentina

*Corresponding author: charlesadrianoduvoisin@gmail.com 
context, an innovative apparatus was invented, based on the electrons trap, in order to completely electro-neutralize alkali and acidic agrochemicals located in the internal and external parts of foods as well as those parts dispersed in water.

\section{Materials and methods}

An apparatus was built and protected under patent application (Duvoisin, 2016). The method of this pilot device system is based on an electron added to the previous polarization through electromagnetic physical action (Duvoisin, 2018a; Duvoisin, 2018b; Duvoisin et al., 2018). The equipment size is $3 \times 2 \times 3$ m, with Faraday cage due high voltage of 8 to $100 \mathrm{kV}$ range. The electrode is made from inox steel $316 \mathrm{~L}$, the equipment has a sample holder and control panel as shown in Figure 1.

The equipment was connected to high voltage electrical sources $(4,8,30$ and $40 \mathrm{KV})$ with electron orientation (+ and -) so it was possible to evaluate the necessary time and energy quantity needed for the acidification and alkalinization process of the electrolytic medium in question as exposed in the next section. The Figure 2 shows the Spark-gap method used to verify the accumulation of electric charges and method used to verify the potential difference change in limes in natura.

For the verification of the effect caused by the process in relation to the physic-chemical characteristics of the electrolyte,

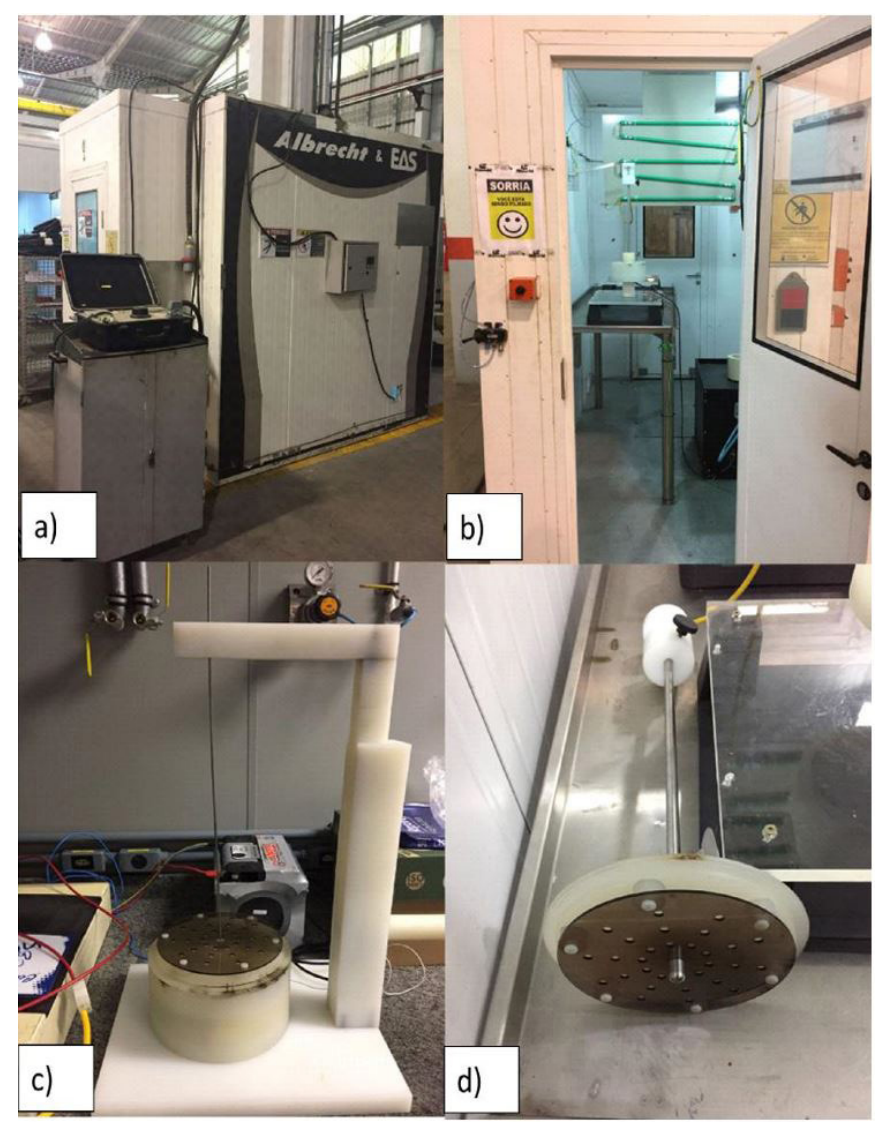

Figure 1. Electro-neutralizer apparatus. Legend: a) External view; b) chamber internal view; c) sample holder; d) electro-neutralizer device in detail (spark generator). the $\mathrm{pH}$ and temperature changes were analyzed using four water samples collected in different regions of Brazil, better described below:

- Distilled water (DW) obtained from purification system (Fisatom, 534).

- Mineral water mark 1 (WM1) collected and packed original from Palhoça - SC, under coordinates 27³7’43.2 “S $48^{\circ} 41^{\prime} 17.9^{\prime \prime} \mathrm{W}, 3 \mathrm{~m}$ altitude.

- Mineral water mark2 (WM2) collected and packed original from Águas da Prata - SP, under coordinates $21^{\circ} 56^{\prime} 22.3^{\prime \prime S}$ $46^{\circ} 42^{\prime} 56.3^{\prime \prime W}, 838 \mathrm{~m}$ altitude.

- Water from public network (WPN) collected in São Bento do Sul - SC, under the coordinates $26^{\circ} 14^{\prime} 41.8^{\prime \prime S}$ $49^{\circ} 22^{\prime} 58.0$ “W, $838 \mathrm{~m}$ altitude.

A $\mathrm{pH}$ meter (AKSO, AK90) was used to measure $\mathrm{pH}$ and temperature of samples. Measurements were taken before the start of the process and over the periods of 30/60/90/120/300/600/900/1200 seconds.

For the verification of the effect caused by the process with respect to the amount of electrolyte used, the $\mathrm{pH}$ and temperature change during the process three different quantities of electrolytes based on aqueous solution were analyzed, in order to analyze different electrical accumulation. For this, $25 \mathrm{~mL}$ was used for sample 1 (AM1), $50 \mathrm{~mL}$ for sample 2

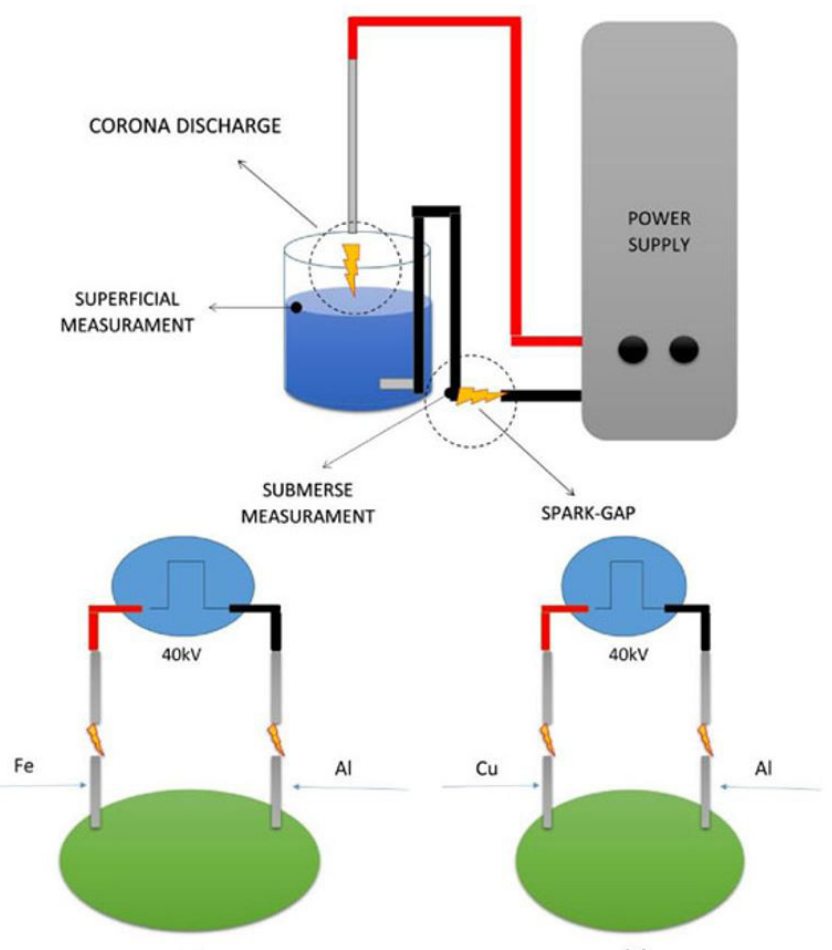

(A)

(B)

Figure 2. Spark-gap method used to verify the accumulation of electric charges and method used to verify the potential difference change in limes in natura. 
(AM2) and $100 \mathrm{~mL}$ for sample 3 (AM3). Measurements were taken before the start of the process and in the periods of $30 / 60 / 90 / 120 / 300 / 600 / 900 / 1200$ seconds. For the verification of the effect caused by the equipment, the change in $\mathrm{pH}$ and temperature during the process, three different initial temperatures of the aqueous solution-based electrolyte were analyzed. In the assays, $25 \mathrm{~mL}$ was used, and the initial temperatures used were $5{ }^{\circ} \mathrm{C}$ for sample $1,20^{\circ} \mathrm{C}$ for sample 2 and $35^{\circ} \mathrm{C}$ for sample 3 . Measurements were performed before the start of the process and in the periods of 30/60/90/120/300/600 seconds.

The standardization of electrolyte aqueous solution was used due to the agrochemicals present in many variables (dissolution), which would require a lot of time for the standardization of the variables of these samples.

\subsection{Analysis of retention and accumulation of electric charges}

For the verification of the storage of electric charges by the equipment, the process was carried out over a period of 5 seconds, then the potential difference measurement was made and the reading was repeated after 1 minute of assay. The electrolyte aqueous solution used was $25 \mathrm{~mL}$. The measurement of the voltage stored in the water was made shortly after the energizing process. To read the voltage an oscilloscope was used (ICEL, DSO-2072) with configuration of probe $\mathrm{x} 10$ and display configuration of $20 \mathrm{~V} / 200 \mathrm{mS}$ per division. Three samples with two replicates were tested to confirm the repeatability of the process used. Additionally, an oscilloscope (SIGLENT, SDS1062CM) was also used to verify the energy stored in samples of water in its liquid and solid state (ice cubes) in order to analyze the physical state of matter.

\subsection{Verification of potential difference change and retention and accumulation of electric charges in fruits and vegetables}

The aim of the assay was to verify if there was potential difference changes after the application of pulsed high voltage using two electrodes inserted in limes (given their natural acidity). To verify the change, a $40 \mathrm{kV}$ (direct current) pulsed source was used. The acidic juice from the limes (Citrus latifolia) represents about $50 \%$ of the fruit weight and the ascorbic acid content varies from 20 to $40 \mathrm{mg} / 100 \mathrm{~mL}$ of juice (Coelho et al., 2004). For the application of the high voltage, electrodes of stainless steel, iron, aluminum and copper were used with the same dimensions of $4 \mathrm{~cm} \times 1 \mathrm{~mm}$. The potential difference measurement was performed using a digital multimeter (Hikari, HM-2010). The period of tension application was of 10 and 15 minutes, with voltage reading at every 5 minutes.

The assay methodology used was based on the principles of the Daniell Cell (Martins, 1990) with variation between the materials of the electrodes inserted in the limes.

- In analysis $\mathrm{A}$, iron (positive) and aluminum (negative) electrodes were used.

- In analysis B, copper (positive) and aluminum (negative) electrodes were used.
A 2-mm spark-gap was left between the electrodes inserted in the limes using high voltage source, with the function of avoiding the return of the electric current to the source coil (positive) and to the (negative) battery.

In order to prove that the electro-neutralization occurs in the internal part of the fruits and vegetables, the energy quantification contained in each fruit was measured using an oscilloscope. The fruits and vegetables tested were: apple (Malus Communis), orange (Citrus sinensis L. Osbeck), papaya (Carica papaya), lime (Citrus latifolia), banana (Musa spp.), cucumber (Cucumis sativus) and tomato (Solanum lycopersicum).

\section{Results and discussion}

The results concerning the $\mathrm{pH}$ and temperature changes are shown in Figure 3 exposed below:

It is possible to observe the temperature increased similarly in all types of electrolyte aqueous solution. However, the $\mathrm{pH}$ reduction was more significant in both DW and WPN samples. The samples WM1 and WM2 showed a lower reduction in $\mathrm{pH}$ with a longer delay to initiate $\mathrm{pH}$ variation. Thus, it is noted that, regardless of the aqueous solution-based electrolyte used in the process, there are $\mathrm{pH}$ changes, wherein the duration of the process has a great influence on the results.

The results regarding the $\mathrm{pH}$ and temperature changes of aqueous solution-based electrolyte in relation to the duration of the process are shown in Figure 4.

As can be seen in Figure 4 sample A, it is possible to observe a greater change in both $\mathrm{pH}$ and temperature values over the first 300 seconds. From this moment the variation of the values is more subtle showing process stability. In sample $\mathrm{B}$, the $\mathrm{pH}$ stabilization occurs after 600 seconds, showing a short variation when compared to the previous sample $(25 \mathrm{~mL})$. In sample C, the temperature change (increasing) was very similar in both samples $1(25 \mathrm{~mL})$ and $2(50 \mathrm{~mL})$, however it was not possible to observe changes in the $\mathrm{pH}$ value $(100 \mathrm{~mL})$.

In general, it is possible to observe, in the time of 300 seconds, a decrease of the $\mathrm{pH}$ value, which is inversely proportional to the initial temperature, i.e., the lower the initial temperature the greater the decrease in $\mathrm{pH}$ value. However, the total variation of $\mathrm{pH}$ in time of 600 seconds is very similar in all samples, with a maximum difference change of 0.4 in the $\mathrm{pH}$ value.

\subsection{Analysis of retention and accumulation of electric charges}

The results obtained in both surface and submerged measurements can be observed in Figure 5, showing the electron retention capacity of the device.

Measured voltage pulse shows the accumulated electric charge. After the maximum measured voltage peak (Figure 5, samples a and c) the value approaches zero due to electrons loss through the measuring equipment. After 1 minute of assay the measurement was performed again and it can be observed that the differential potential value is lower than the previous read value and greater than zero (Figure 5 samples $b$ and d). This 

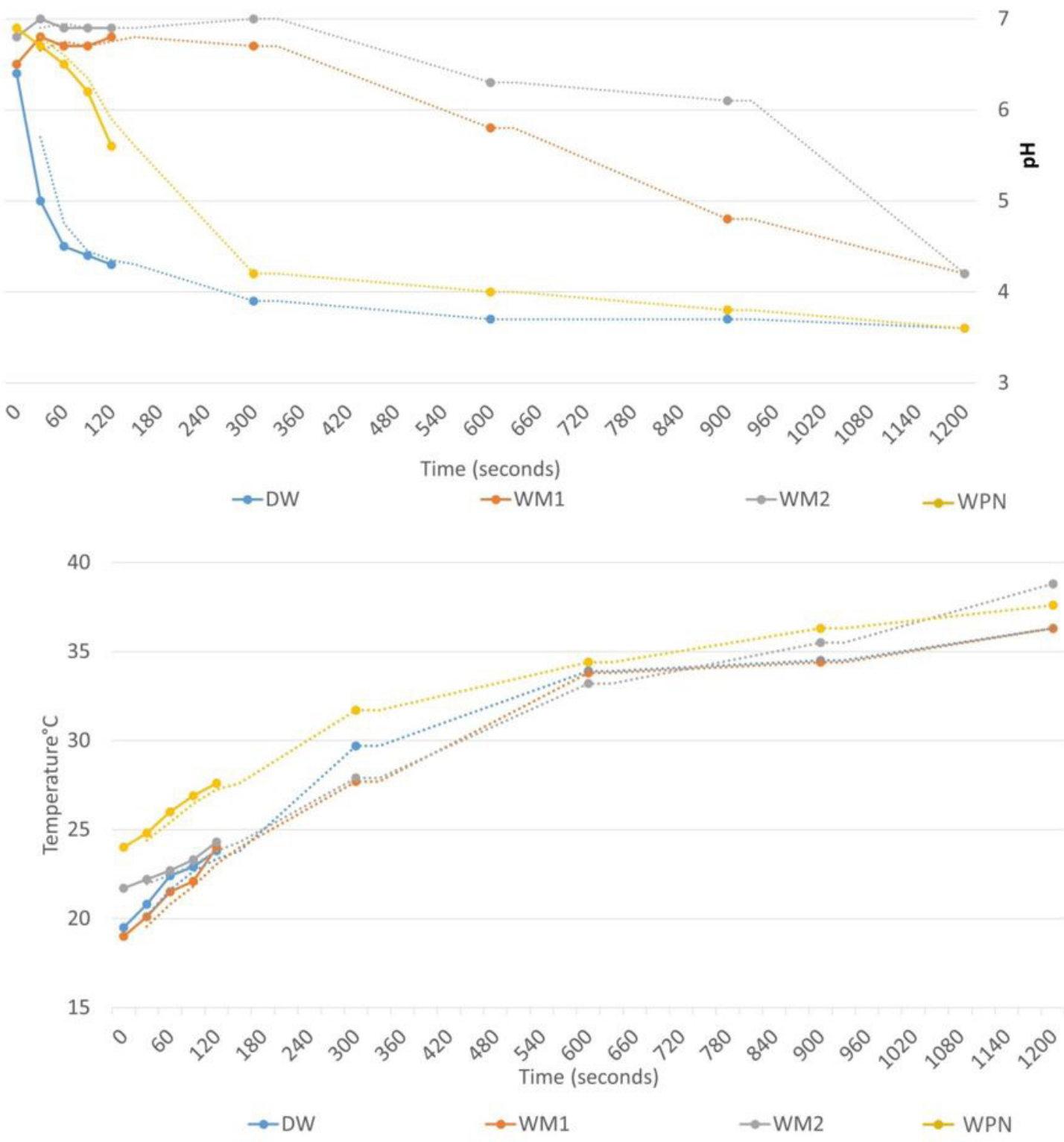

Figure 3. $\mathrm{pH}$ and temperature changes in the four types of electrolyte aqueous solution. Legend: distilled water (DW); - mineral water 1 (WM1); mineral water 2 (WM2); water from public network (WPN).

indicates an electric redistribution in the electrolyte, justifying an electrostatic recharging.

In order to verify the accumulation of electric charges, measurements were made in 4 steps. The first measurement was made before the energizing process, as shown in Figure 5, sample e; the second measurement was made immediately after energizing, as shown in sample $\mathrm{f}$; the third measurement was made after 7 hours with complete freezing of the water, as shown in sample g; and the fourth measurement was made after the defrosting of the water, completely returning to the liquid state, as shown in Figure 5, sample h).

Thus, it was possible to observe that even having a sample changing from the liquid to the solid (ice; frozen water) and returning to the liquid state, it still maintained the storage of electric charges, occurring only loss of a portion of energy when it returns to the liquid state.

\subsection{Verification of potential difference change and retention and accumulation of electric charges in fruits and vegetables}

In both methodologies (electrons trap and Daniell Cell) it was possible to observe increases in the potential difference measurements. Figure 6 shows the electron trap scheme.

Electrical distribution is observed throughout the electrolyte area, not just in the surface. The value of the accumulated electric charge varies according to the applied voltage, spacing of the spark-gap, type of electrolyte and amount of electrolyte.

Figure 7 ( $a$ and $b$ ) shows the accumulation of electric charges in lime samples, it is possible to observe a significant increase 

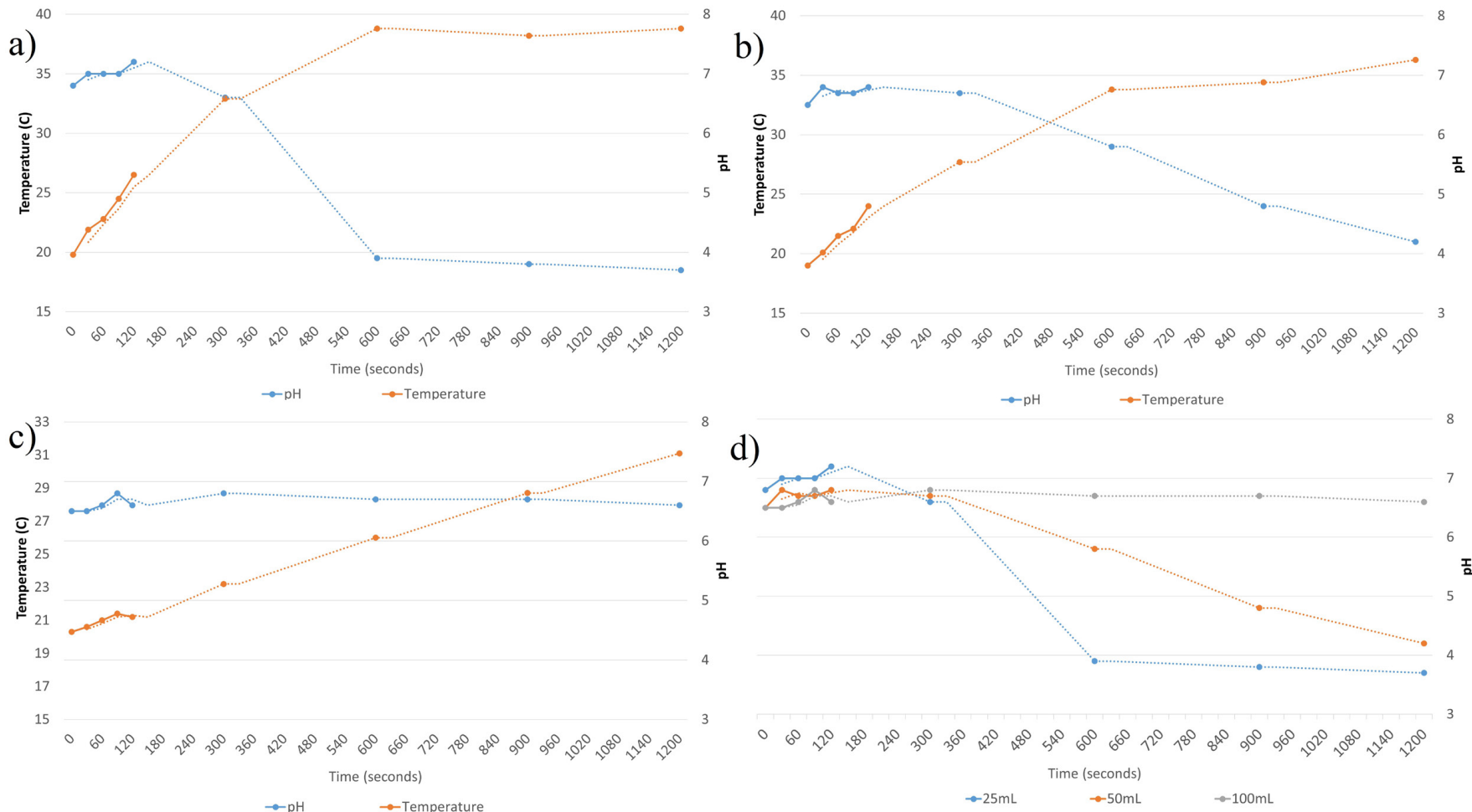

d)
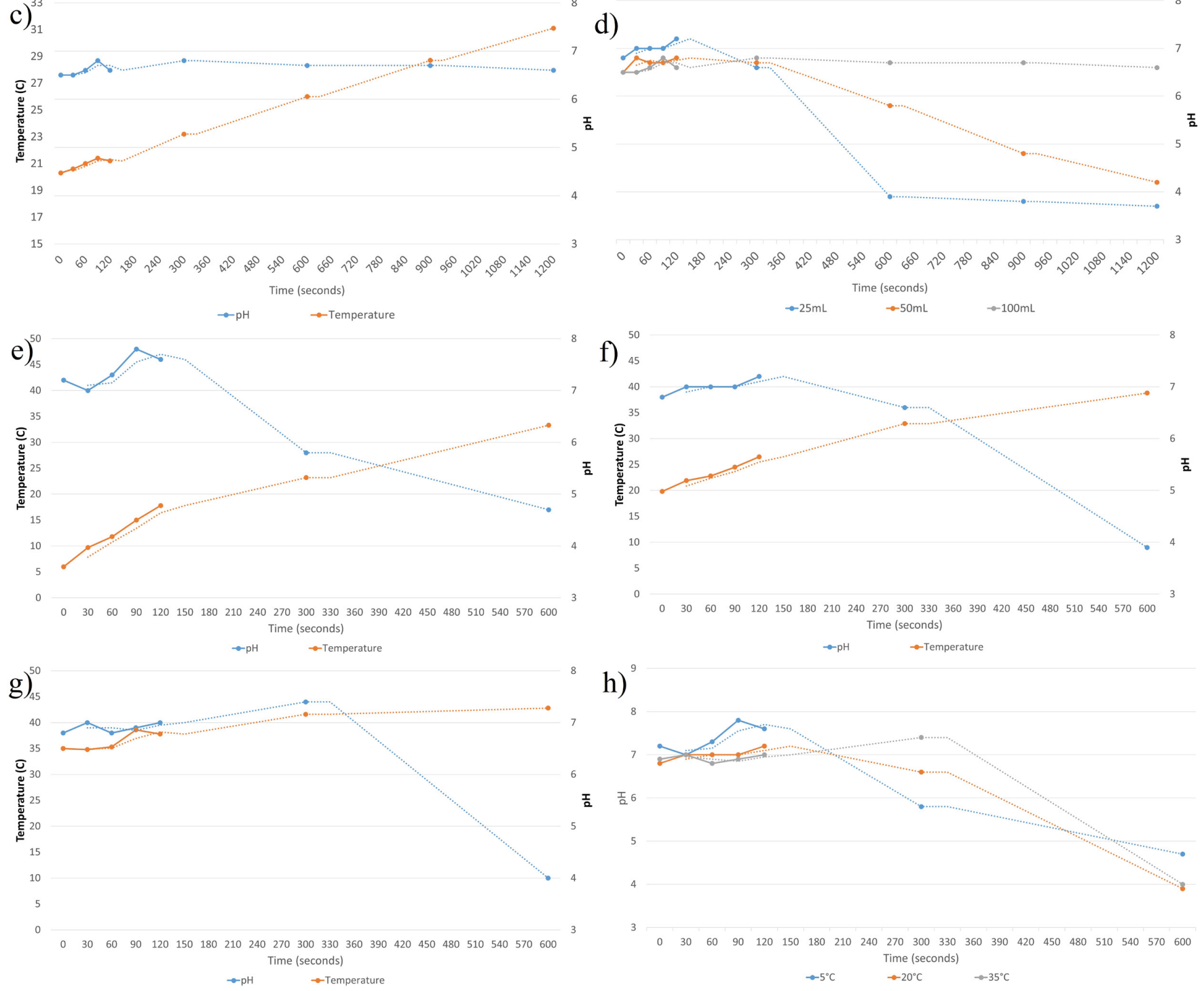

h)

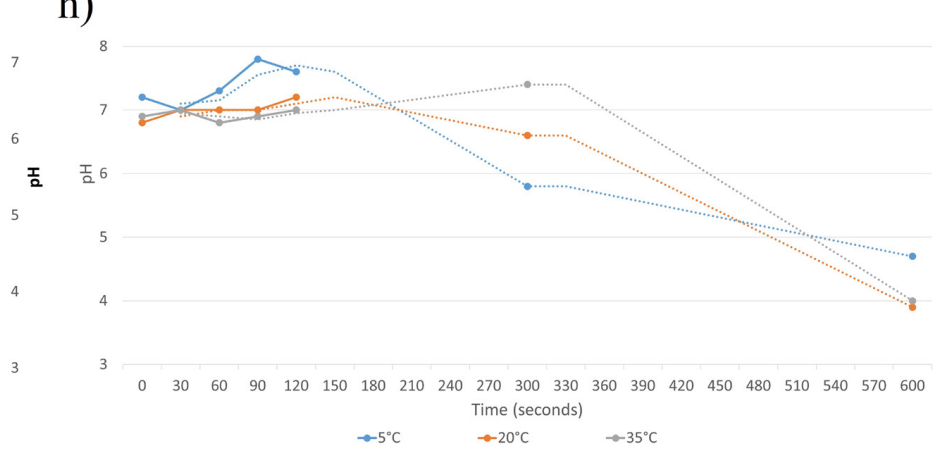

Figure 4. $\mathrm{pH}$ and temperature changes of aqueous solution-based electrolyte in relation to the duration of the process. Legend: a) $\mathrm{pH}$ and temperature changes using $25 \mathrm{~mL}$ of electrolyte aqueous solution; b) $\mathrm{pH}$ and temperature changes in $50 \mathrm{~mL}$ of aqueous solution; c) pH and temperature changes in $100 \mathrm{~mL}$ of electrolyte aqueous solution; d) comparison of the $\mathrm{pH}$ change between samples of $25 \mathrm{~mL}, 50 \mathrm{~mL}$ and $100 \mathrm{~mL}$ in relation to the duration of the process; e) $\mathrm{pH}$ and temperature changes in $25 \mathrm{~mL}$ of aqueous solution at initial temperature of $5{ }^{\circ} \mathrm{C}$; $\mathrm{f}$ ) $\mathrm{pH}$ and temperature changes in $25 \mathrm{~mL}$ of aqueous solution-based electrolyte in relation to the process duration at initial temperature of $20^{\circ} \mathrm{C}$; g) $\mathrm{pH}$ and temperature changes in $25 \mathrm{~mL}$ of aqueous solution-based electrolyte at initial temperature of $35^{\circ} \mathrm{C} ; \mathrm{h}$ ) comparison of the pH change between the samples with respect to the initial temperature. 
after the first 5 minutes of electric voltage application. After this period the stabilization of value occurs.

The energetic quantification measured in the internal part of each fruit and vegetable was the same than that of the aqueous electrolytic medium. The papaya and cucumber samples remained with part of their volume outside the aqueous electrolyte medium (sample holder), and the internal energies measured proved to be the same in comparison to the others samples (totally submerged). Additionally, in Figure 7c, it is possible to observe the stored electric charge in fruit and vegetable samples.
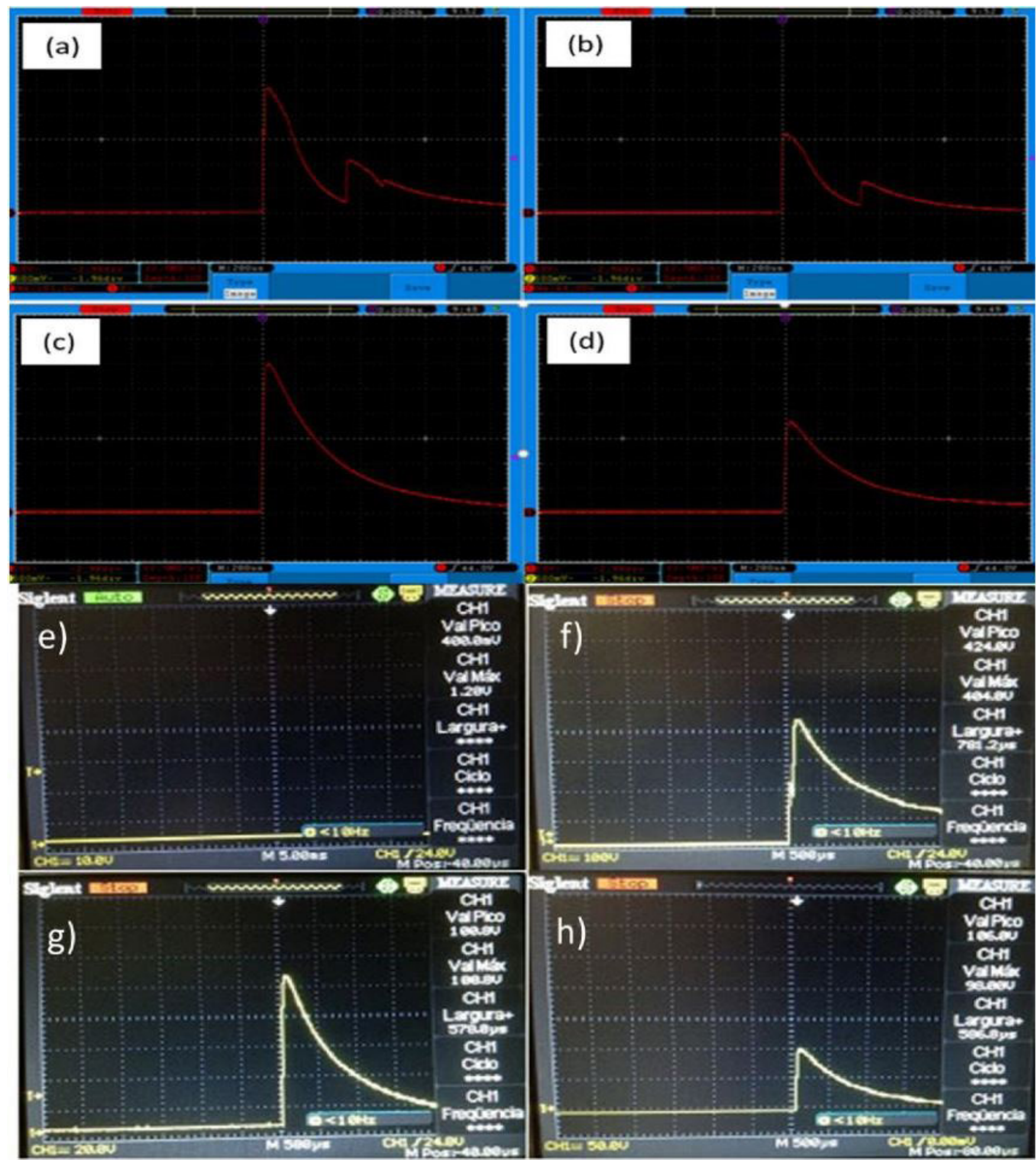

Figure 5. Energization measurement of water samples in different physical states. Legend: samples a) and b) superficial; samples c) and d) submerged after 1 minute; e) before energizing; f) after energizing in a liquid state; g) after solid state of energizing; h) in liquid state after defrosting. 
CONTROLLED AND DIRECTED ELECTRON TRAP

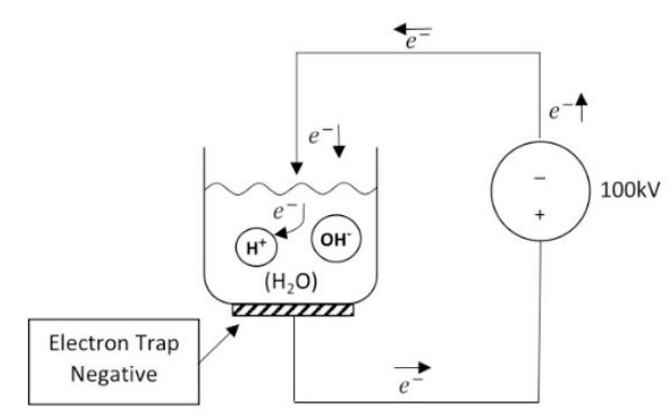

5 Alkaline



CONTROLLED AND DIRECTED ELECTRON TRAP
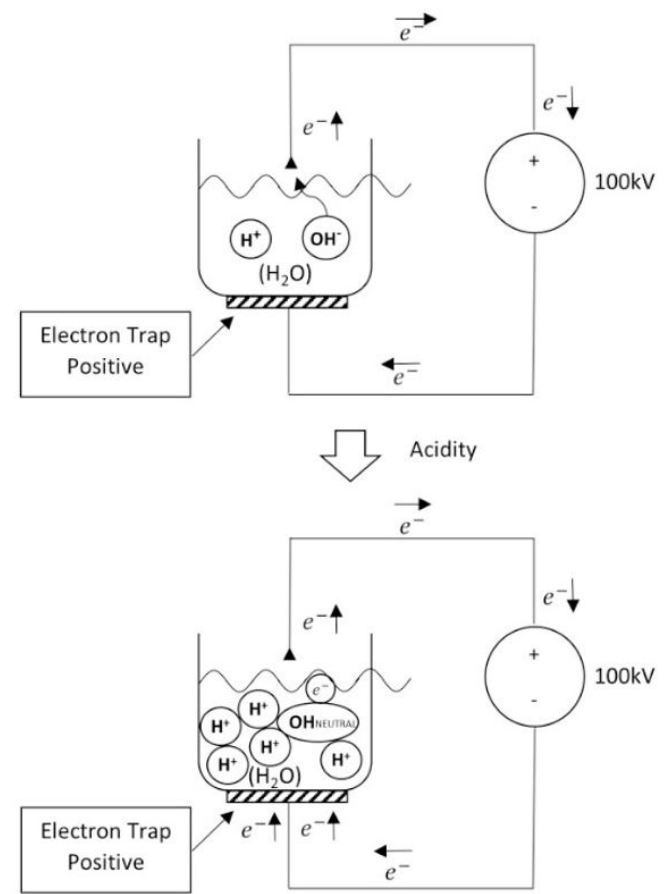

Figure 6. Electrons trap scheme.

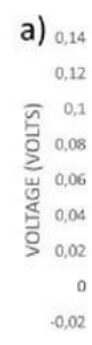

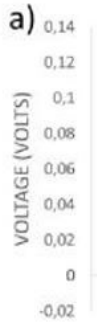

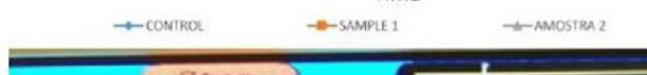

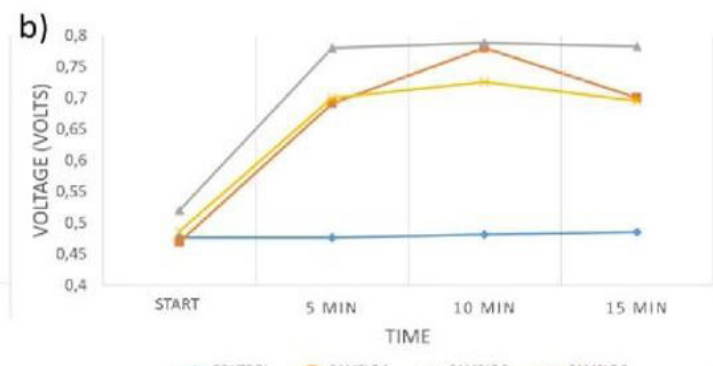

$\rightarrow$ CONIROL $\rightarrow$ SAMPIE $1 \rightarrow$-SAMPLE $2-$ SAMPLE 3

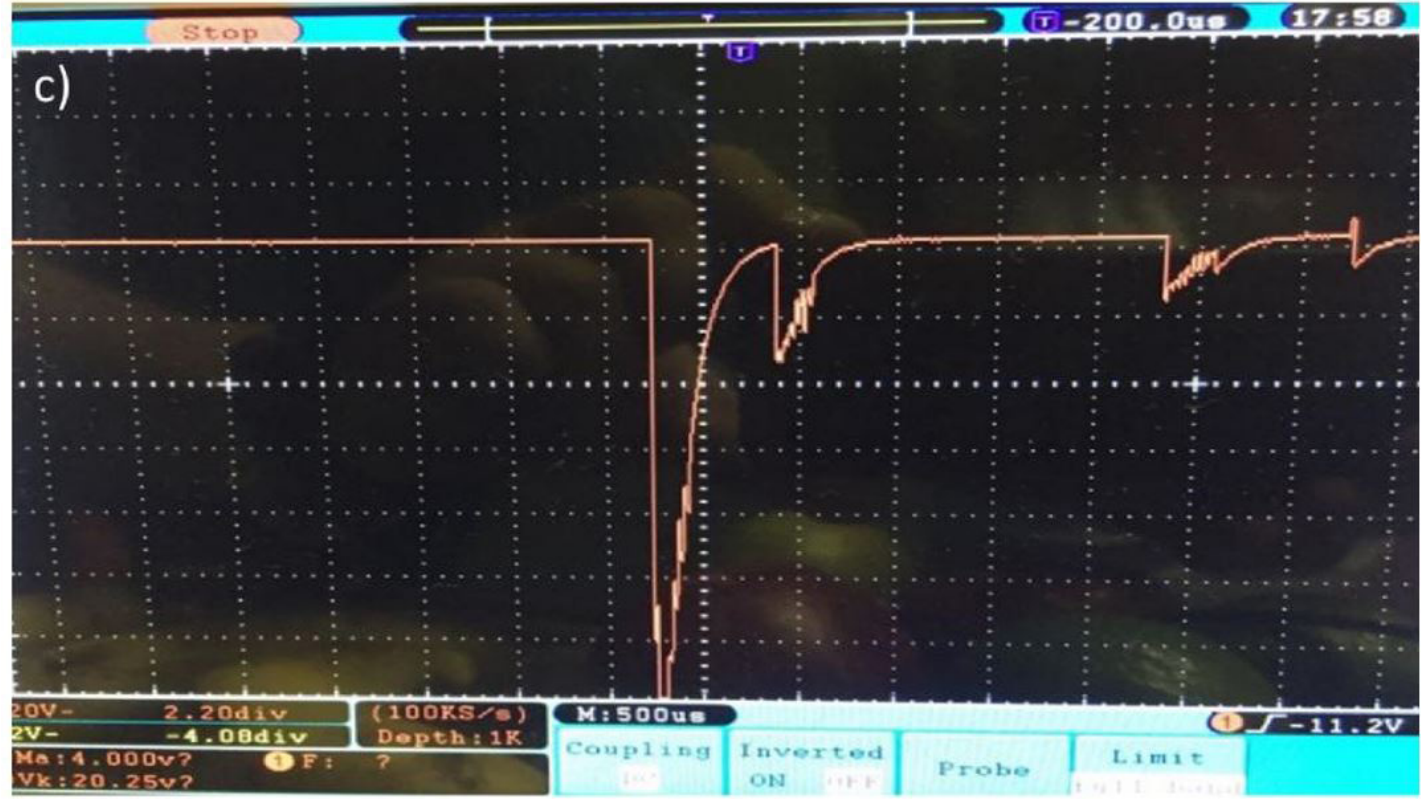

Figure 7. Accumulation of electric charges in lime samples ( $a$ and b); stored electric charge in fruit and vegetable samples (c). 


\section{Discussion}

Based on the scientific evidence exposed and the promising results of this work, it is possible to plan an interesting future for the commercial and industrial technological search for the electro-neutralization of agrochemicals in contaminated food and water samples.

In 2010, the Brazilian agrochemical market handled $\$ 7.3$ billion and accounted for 19\% of the global market. Soy, corn, cotton and sugarcane represent $80 \%$ of total sales in this sector. According to the Brazilian Association of Collective Health - ABRASCO, this is the list of agriculture products which require pesticides the most: soybean (40\%), corn (15\%), sugarcane and cotton (10\% each), citrus (7\%), coffee, wheat and rice $(3 \%)$, beans $(2 \%)$, potatoes $(1 \%)$, tomatoes $(1 \%)$, apples $(0.5 \%)$ and bananas $(0.2 \%)$. The other crops consumed represent $3.3 \%$ from the total of 852.8 million liters of agrochemicals sprayed in 2011 (Carneiro et al., 2015).

Only organic food is free from agrochemical, but it is fundamental to create a monitoring and certifying body for these so-called organic products. Also, they can be certainly sold with a higher added value, that is, healthier human life.

The formula for measuring the energy loading of matter depends on the following variables (Equation 1):

$$
\Delta \overrightarrow{\boldsymbol{E}_{i}}=k_{e} \frac{\Delta q_{i}}{r_{i}^{2}} \hat{\boldsymbol{r}}_{i}
$$

If a total electric charge $Q$ is evenly distributed along a volume $V$, the volume charge density $\mathrm{p}$ is defined by (Equation 2):

$\rho \equiv Q / V$

Where $\rho$ represents Coulomb units per cubic meter.

If $Q$ is evenly distributed over an area $A$, the surface charge density $o$ will be defined by (Equation 3):

$\sigma \equiv Q / A$

Where $\sigma$ represents Coulomb units per square meter.

When we increase tensions significantly, the resistances of dielectrics materials usually reduce their capacity of facilitating the passing of electrons, as stated by Ohm's law.

The technology exposed here is based on electron traps made of electrically resistant materials using high voltages, in order to capture an amount of electrons so the effect of electron storage or deficit will occur, thus creating a potential differential against the accumulation of electrons.

With the ideal design of this model, many types and forms of systems and methods capable of neutralizing agrochemicals or similar agents will be achieved for both solid and liquid samples.

A constant that contemporary science highlights in the matter of prevention of consumption of food contaminated by agrochemicals is the care that before consuming them, it is necessary to maintain them in alkaline or acidic means, aiming to neutralize the greatest part of toxins from agrochemicals.
However, according to the National Health Surveillance Agency - ANVISA, most agrochemicals sold in Brazil are acidic. However, there are many alkaline types of agrochemicals (including alkaline) and its ineffectiveness by immersion under alkaline or acidic solutions would not have an ideal effect. Depending on the situation for an effective chemical neutralization of agrochemicals toxins, using acid or basic solution will only have a superficial action, as the internal penetration of the chemical solutions inside the food takes place, making this process ineffective (Agência Nacional de Vigilância Sanitária, 2014, 2018; Belmonte, 2018; Carneiro et al., 2015).

Thus, the technology exposed in this study provides a strong assumption for the electro-neutralization of both acidic and basic agrochemicals, by controlling the change of the electron flow, since it has already been proven in the literature that the positive flow of electrons tend to a deficit of electrical potential differential resulting in the decrease of the $\mathrm{pH}$ of the electro-neutralized medium. That is, an acidic result of the medium, as well as the backflow of negative electrons tend to a excessive entrapment of electrons, resulting in an electrical potential differential with leftover electrons and thus tending to alkalize the medium.

The system and method proposed in this work have the capacity to provide direct electron flow as necessary for the neutralization of the electrolytic medium in question, i.e. if the medium to be neutralized supposedly contain toxic agrochemicals or byproducts, there will be a reading of this medium through sensors, which have the ability to read the acid or basic condition of the medium to be electro-neutralized, achieving an ideal physical-chemical neutralization of toxins contained in this medium. An important detail is the electro-neutralization of toxins located in the innermost parts of the food. It was possible to observe the efficacy of $\mathrm{pH}$ alteration verified and measured in the outermost parts and in the innermost parts of in natura limes; it was perceived a complete energization of the citrus fruits tested. It was also observed the complete energization of the electrolytic media in water samples.

The toxicity of agrochemicals can be measured by its ionization capacity, so it can be observed that a specific agrochemical is not as acidic or basic since it may have as elementary characteristic the property of degradation with ion-forming capacity, for either acidic or basic media.

Concerned with this ions forming capacity, we also made tests with longer electrolysis times in order to test the physical action of the electron trap. It was perceived that impure water samples have a specific time to modify its chemical bonding, as they tend, at a certain moment, to acidify and, after stabilized in another moment, they tend to alkalize the media and vice versa.

Many chemicals underwent uncontrollable chemical reactions, but when these were subjected to the physical effects of electron traps (stabilized) they tend to energize or de-energize under the effects of the proposed electro-neutralizing apparatus.

The energetic accumulation of the medium occurs without significant changes in relation to the same, providing the hypothesis of the organoleptic preservation of the foods to be purified by using this method. 
Based on the test result it was verified that the electro-neutralizer system also acts in the innermost parts of any corresponding liquid or solid, therefore the electro-neutralization occurs in a constant and complete ways.

The ability to energize liquids or solids (foods) proves that directing the flow of electric current provides the acidification and alkalinization of the means (Ahmed, 2016; Anpilov et al., 2001; Chen et al., 2016; Griffiths et al., 2016; Duvoisin et al., 2017a, b; Duvoisin \& Baggio, 2016; Foster et al., 2012; Garotti, 2018; Hazmi et al., 2013; Julák et al., 2012; Kebriaei et al., 2015; Martins, 1990; Matsumoto et al., 2015). Accordingly, through the scientific evidence exposed in this study, is possible to prove the hypothesis proposed thereby supporting the innovation system of electro-neutralization of agrochemicals.

Diverse scientific evidences were related in this work, proving that the accumulation of energy of any kind always provides varied physical and chemical reactions and logically that many of these reactions are not yet fully understood and dominated (Niva et al., 2016; Nunes \& Espíndola, 2012; Quyen et al., 2017; Santos et al., 2011; Sarantópoulos et al., 2017; Serway \& Jewett, 2014; Souza, 2010; Ten Bosch et al., 2017; Vieira et al., 2002; Xijun et al., 2012). This empirical database provides a dynamic curiosity for future studies, which may lead to revelations not yet well understood, for example: electrostatic accumulation does not provide significant damage to protein denaturation; however it significantly degrade the acids and alkalis conditions in this medium.

This study demonstrated the positive or negative accumulative capacity of electro-neutralization of agrochemicals contained in both solid and liquid samples, a physical process that does not provide heating or aggressive effects to the organoleptic properties of the evaluated foods. The innovation herein presented contributes to the food safety and human health areas.

\section{Final considerations}

Therefore, due to the great amount of scientific evidence which proves the toxicity of the pesticides contained in the food ingested by the world population, technologies having as goal the reduction of the harmful effects of pesticides absorbed by humans will always be welcome.

The scientific meta-analysis carried out in this project proves the practical feasibility of electron trapping through various controlled and directed electron trapping techniques, as well as many more modern articles that have demonstrated the possibility of alkalinizing and acidifying liquid-based water media. However, it is very important to note that directing the electric current will provide either the acidification or alkalinization of the medium in question. This occurs due to electrostatic charging with either positive or negative directed and controlled potential differential.

The experiments carried out in this work demonstrate, in a practical way, the electrostatic energy accumulation in all the fruits and vegetables tested, including the internal and external parts of the same, since the isolation of the outermost part of the electrodes inserted in the fruits was taken care of, as taught by the Daniell cell methodology. Regarding acidification and alkalinization, tests were carried out in different water types, wherein the controlled changes of the $\mathrm{pHs}$ of these tested waters were verified - as well as the positive or negative energy accumulation of both the waters and the foods tested.

Thus, by adding the scientific knowledge with the performed meta-analysis and with the promising practical results of the tests carried out in this work, certainly the proposition of this technological innovation capable of electro-neutralizing pesticides contained in food, by means of the controlled and directed electron trapping, is a well-founded and very important promise for global food security.

\section{Acknowledgements}

The main author is grateful for the post-doctorate internship opportunity supervised by Dr. José Paulo de Sousa at the University of Coimbra - Portugal and also for the post-doctorate internship opportunity supervised by Dr. Rogério de Almeida Vieira at Federal University of São Paulo - Brazil and for the support provided by the Latin-American Institute of Higher Education (IESLA). Professor Dilmar Baretta thanks the CNPq for a Research Productivity Grant (CNPq No. 307162/2015-0). Dr. Diogo J. Horst thanks the scholarship from the Coordenação de Aperfeiçoamento de Pessoal de Nível Superior - Brasil (CAPES) - Finance Code 001.

\section{References}

Agência Nacional de Vigilância Sanitária - ANVISA. (2014). Programa de análise de resíduos de agrotóxicos (PARA): Relatório de atividades de 2012 complementar. Brasília: ANVISA. Retrieved from http://portal. anvisa.gov.br/programa-de-analise-de-registro-de-agrotoxicos-para

Agência Nacional de Vigilância Sanitária - ANVISA. (2018). Risco no consumo de frutas e hortaliças com agrotóxicos. Brasília: ANVISA. Retrieved from http://portal.anvisa.gov.br/resultado-debusca?p_p_id=101\&p_p_lifecycle $=0 \&$ p_p_state $=$ maximized $\&$ p_p_ mode=view\&p_p_c\%20ol_id=column-1\&p_p_col_count=1\&_101_ struts_action=/asset_publisher/view_content\&_101_assetE\%20 ntryId=2862602\&_101_type $=$ content\&_101_groupId=219201\&_101_ urlTitle=risco-no-consumo-de-agrotoxico\&inheritRedirect $=$ true

Ahmed, A. (2016). Effect of positive and negative corona discharge plasmas on the properties of distilled water. Scientific Journal of The Faculty of Basic Education, 22(93), 25-32.

Anpilov, A. M., Barkhudarov, E. M., Bark, Y. B., Zadiraka, Y. V., Christofi, M., Kozlov, Y. N., Kossyi, I. A., Kop’ev, V. A., Silakov, V. P., Taktakishvili, M. I., \& Temchin, S. M (2001). Electric discharge in water as a source of UV radiation, ozone and hydrogen peroxide. Journal of Physics. D, Applied Physics, 34(6), 993-999. http://dx.doi. org/10.1088/0022-3727/34/6/322.

Associação Brasileira de Saúde Coletiva - ABRASCO. (2018). Dossiê ABRASCO. Rio de Janeiro: ABRASCO. Retrieved from http:// contraosagrotoxicos.org/dossieagrotoxicos/

Associação Paranaense das Vitimas Expostas ao Amianto e aos Agrotóxicos - APREAA. (2018, Março 08). Agrotóxicos podem causar câncer, apontam pesquisas. G1. Retrieved from https://g1.globo.com/pr/ parana/especial-publicitario/apreaa/noticia/agrotoxicos-podemcausar-cancer-apontam-pesquisas.ghtml

Bassil, K. L., Vakil, C., Sanborn, M., Cole, D. C., Kaur, J. S., \& Kerr, K. J. (2007). Cancer health effects of pesticides: Systematic review. 
Canadian Family Physician Medecin de Famille Canadien, 53(10), 1704-1711. PMid:17934034.

Bastos, L. H. P., Cardoso, M. H. W. M., Nóbrega, A. W., \& Jacob, S. C. (2011). Possíveis fontes de contaminação do alimento leite, e estudos de monitoramento de seus resíduos: uma revisão nacional. Cadernos Saúde Coletiva, 19, 51-60.

Belmonte, T. (2018, Maio 8). Pesquisas associam câncer ao uso intensivo de agrotóxicos nas lavouras. Extra Classe. Available https: //www. extraclasse.org.br/edicoes/2018/05/pesquisas-associam-cancer-aouso-intensivo-de-agrotoxicos-nas-lavouras/.

Carneiro, F. F., Augusto, L. G. S., Rigotto, R. M., Friedrich, K., \& Búrigo, A. C. (2015). Dossiê ABRASCO: Um alerta sobre os impactos dos agrotóxicos na saúde. Rio de Janeiro/São Paulo: EPSJV/Expressão Popular.

Chen, B., Zhu, C., Fei, J., He, X., Yin, C., Wang, Y., Gao, Y., Jiang, Y., Wen, W., \& Chen, L. (2016). Yield of ozone, nitrite nitrogen and hydrogen peroxide versus discharge parameter using APPJ under water. Plasma Science \& Technology, 18(3), 278-286. http://dx.doi. org/10.1088/1009-0630/18/3/11.

Coelho, Y., Magalhães, A., Passos, O., Nascimento, A., Santos Filho, H. P., \& Soares Filho, W. S. (2004). A cultura do limão-taiti. Brasilia: Embrapa Informação Tecnológica. Retrieved from https://www. infoteca.cnptia.embrapa.br/infoteca/handle/doc/119233

Duvoisin, C. A (2016). Sistema e método para neutralização de agrotóxicos ou agente similares contidos em alimentos e configuração construtiva para sua implementação. BR 102016 026848-6 e PCT/ BR 2017/050115. INPI.

Duvoisin, C. A (2018a). Sistema e método de condensação de ondas eletromagnéticas através de campos elétricos e magnéticos modulados e equipamento de condensação de ondas eletromagnéticas correspondente. BR 102018068980-0/870180131765. INPI.

Duvoisin, C. A (2018b). System and method for neutralizing pesticides or similar agents contained in foodstuffs and structural arrangement for implementing same. WO/2018/090110, PCT/BR2017/050115. Rio do Sul, SC: Cerumar Serviços em Propriedade Intelectual.

Duvoisin, C. A. and Baggio, F. E. (2016). Patente do Sistema e método para energização de água e equipamentos correspondentes. PCT/ BR2016/050154.

Duvoisin, C. A., Horst, D. J. H., Vieira, R. A., Afonso de Souza, J. P. F., Baretta, D., Pscheidt, A., Mourão Jr., C. A., Secchi, M. A., Bernardes, S., Froehner, J. (2018). System and method to electro-neutralize agrochemicals from food and water. London Journal of Research in Science: Natural and Formal, 18(4), 1-2.

Duvoisin, C., Pscheidt, A., \& Dagios Neto, E. (2017a). Uma nova abordagem da física para construção da "Máquina do Tempo" (1st ed., 240 p.). França: Novas Edições Acadêmicas.

Duvoisin, C., Secchi, M., \& Dagios, V. (2017b). Conceitos físicos de eletrólises, uma nova era de segurança alimentar (1st ed., 116 p.) França: Nova Edições Acadêmicas.

Eustachewich, L. (2018, April 30). Pesticide linked to cancer is in nearly every US food: report. New York Post. Retrieved from https:// nypost.com/2018/04/30/pesticide-linked-to-cancer-is-in-nearlyevery-us-food-report/

Food and Drug Administration - FDA. (2011). Pesticide Residue Monitoring 2011. Silver Spring: FDA. Retrieved from https://wayback. archive-it.org/7993/20170722164638/https://www.fda.gov/Food/ FoodborneIllnessContaminants/Pesticides/ucm383332.htm

Foster, J., Sommers, B. S., Gucker, S. N., Blankson, I. M., \& Adamovsky, G. (2012). Perspectives on the interaction of plasmas with liquid water for water purification. IEEE Transactions on Plasma Science, 40(5), 1311-1323. http://dx.doi.org/10.1109/TPS.2011.2180028.

Garotti, H. (2018). As quatro forças fundamentais da natureza. If.ufrgs. br. Retrieved from http://www.if.ufrgs.br/tex/fis01043/20032/ Humberto/index.html [Accessed 5 Oct. 2018]

Griffiths, B. S., Römbke, J., Schmelz, R. M., Scheffczyk, A., Faber, J. H., Bloem, J., \& Stone, D. (2016). Selecting cost effective and policy-relevant biological indicators for European monitoring of soil biodiversity and ecosystem function. Ecological Indicators, 69, 213-223. http://dx.doi.org/10.1016/j.ecolind.2016.04.023.

Hazmi, A., Desmiarti, R., Waldi, E. P., \& Darwison, D. (2013). Removal of microorganisms in drinking water using a pulsed high voltage. Journal of Engineering and Technological Sciences, 45(1), 1-8. http:// dx.doi.org/10.5614/j.eng.technol.sci.2013.45.1.1.

Instituto Nacional de Câncer - INCA. (2010). Registros hospitalares de câncer, planejamento e gestão (2nd ed.). Rio de Janeiro: INCA. Retrieved from http://bvsms.saude.gov.br/bvs/publicacoes/inca/ registros_hospitalares_cancer.pdf

Instituto Nacional de Câncer - INCA. (2018). Alimentação, nutrição e câncer. Rio de Janeiro: INCA. Retrieved from http://www2.inca. gov.br/wps/wcm/connect/cancer/site/prevencao-fatores-de-risco/ alimentacao/agrotoxicos

Jardim, I. C. S. F., Almeida Andrade, J., \& Queiroz, S. C. D. N. (2009). Resíduos de agrotóxicos em alimentos: uma preocupação ambiental global - um enfoque às maçãs. Quimica Nova, 32(4), 996-1012. http:// dx.doi.org/10.1590/S0100-40422009000400031.

Julák, J., Scholtz, V., Kotúčová, S., \& Janoušková, O. (2012). The persistent microbicidal effect in water exposed to the corona discharge. Physica Medica, 28(3), 230-239. http://dx.doi.org/10.1016/j.ejmp.2011.08.001. PMid:21925912.

Kebriaei, M., Ketabi, A., \& Niasar, A. H. (2015). Pulsed corona discharge, a new and effective technique for water and air treatment. Biological Forum, 7(1), 1686-1692.

Magalhães, M., Guimarães, R., Ferla, L., \& Costa, G. (2018, Janeiro 01). Agrotóxico, o perigo invisível: o veneno e o câncer. $R 7$. Retrieved from https://noticias.r7.com/brasil/agrotoxico-o-perigo-invisivelo-veneno-e-o-cancer-31012018

Martins, G. F. (1990). Why the Daniell cell works! Journal of Chemical Education, 67(6), 482. http://dx.doi.org/10.1021/ed067p482.

Masur, L. (2018, August 13). Shocking verdict supports those who avoid food pesticides. Kitchn. Retrieved from https://www.thekitchn. com/monsanto-verdict-pesticide-cancer-cause-evidence-261413

Matsumoto, K., Toya, Y., Shimasaki, S., \& Taniguchi, S. (2015, Oct 1216). Electrification of droplet by applying high-voltage for spherical silicon solar cell. In Groupe Élaboration par procédés magnétiques (Saint-Martin d'Hères, Isère). 8th International Conference on Electromagnetic Processing of Materials. Cannes, France: SIMAP laboratory/EPM group.

Mourão, C. A., \& Marques Abramov, D. (2013). Biofísica essencial (1st ed., p. 212). Rio de Janeiro: Grupo Gen - Guanabara Koogan.

Niva, C. C., Niemeyer, J. C., Júnior, F. M. R. D. S., Nunes, M. E. T., Sousa, D. L., Aragão, C. W. S., Sautter, K. D., Espindola, E. G., Sousa, J. P., \& Römbke, J. (2016). Soil ecotoxicology in Brazil is taking its course. Environmental Science and Pollution Research International, 23(11), 11363-11378. http://dx.doi.org/10.1007/s11356-016-6597-1. PMid:27072030.

Nunes, M. E. T., \& Espíndola, E. L. G. (2012). Sensitivity of Eisenia andrei (Annelida, Oligochaeta) to a commercial formulation of abamectin in avoidance tests with artificial substrate and natural soil under 
tropical conditions. Ecotoxicology, 21(4), 1063-1071. http://dx.doi. org/10.1007/s10646-012-0859-6. PMid:22297724.

Oliveira, G. V., Révillion, J. P. P., \& Souza, A. R. L. (2016). O risco à saúde dos brasileiros no consumo de frutas, legumes e verduras (FLVs) com resíduos de agrotóxicos e as oportunidades emergentes. Revista Brasileira de Agroecologia, 11(2), 129-139.

Peres, F., Silva, J., \& Rosa, H. (2005). Desafios ao estudo da contaminação humana e ambiental por agrotóxicos. Ciencia \& Saude Coletiva, 27(Suppl.), 27-37. http://dx.doi.org/10.1590/S1413-81232005000500006.

Quyen, N. T., Traikool, T., Nitisoravut, R., \& Onjun, T. (2017). Improvement of water quality using dielectric barrier discharge plasma. Journal of Physics: Conference Series, 860, 1-7. http://dx.doi. org/10.1088/1742-6596/860/1/012031.

Rosalles, M. (2017, Julho 11). Pesquisadora do Instituto Nacional do Câncer alerta sobre os riscos dos agrotóxicos. Brasil de Fato. Retrieved from https://www.brasildefato.com.br/2017/07/11/pesquisadora-doinstituto-nacional-do-cancer-alerta-sobre-os-riscos-dos-agrotoxicos/

Rossi, M. (2015 Abril 30). O "alarmante" uso de agrotóxicos no Brasil atinge $70 \%$ dos alimentos. El País. Retrieved from https://brasil. elpais.com/brasil/2015/04/29/politica/1430321822_851653.html

Santos, L. P., Ducati, T. R. D., Balestrin, L. B. S., \& Galembeck, F. (2011). Water with excess electric charge. The Journal of Physical Chemistry C, 115(22), 11226-11232. http://dx.doi.org/10.1021/jp202652q.

Sarantópoulos, C., Oliveira, L., Padula, M., Coltro, L., Alves, R., \& Garcia, E. (2017). Embalagens plásticas flexíveis: principais polímerose avaliação de propriedades (2nd ed., 432 p.). Campinas: CETEA/ITAL.

Scientific American Brasil (2016). Como alimentar e empregar 10 bilhões de habitantes - Podemos alimentar o mundo e sustentar o planeta? (170 ed.). São Paulo: Scientific American Brasil.

Serway, R., \& Jewett, J. Jr (2014). Princípios de física (1st ed., p. 480). São Paulo: Cengage Learning.
Souza, J. P. F. A. (2010). Scientific Opinion on the development of specific protection goal options for environmental risk assessment of pesticides, in particular in relation to the revision of the Guidance Documents on Aquatic and Terrestrial Ecotoxicology (SANCO/3268/2001 and SANCO/10329/2002). EFSA Jornal, 8(10), 1-55.

Sperb, P. (2016 Agosto 23). Epidemia de câncer? Alto índice de agricultores gaúchos doentes põe agrotóxicos em xeque. BBC News Brasil. Retrieved from http://www.bbc.com/portuguese/brasil-37041324

Ten Bosch, L., Köhler, R., Ortmann, R., Wieneke, S., \& Viöl, W (2017). Insecticidal effects of plasma treatedwater. International Journal of Environmental Research and Public Health, 14(12), 1460. http:// dx.doi.org/10.3390/ijerph14121460. PMid:29186877.

Velleda, L. (2017 Junho 27). Estudo relaciona uso de agrotóxicos com câncer no sangue. Rede Brasil Atual. Retrieved from https://www. redebrasilatual.com.br/saude/2017/06/estudo-relaciona-o-uso-deagrotoxicos-com-o-cancer-no-sangue

Vieira, R. A., Nono, M., \& Cruz, N. C. (2002). Nanohardness of a Ti Thin Film and its interface deposited by an electron beam on 304 SS Subtrat. Physica Status Solidi. B, Basic Research, 232(1), 116-120. http://dx.doi.org/10.1002/1521-3951(200207)232:1<116::AIDPSSB116>3.0.CO;2-1.

World Health Organization - WHO (2016). Pesticide residues in food? Geneva: WHO. Retrieved from http://www.who.int/features/qa/87/en/

World Health Organization - WHO (2018). Pesticide residues in food Geneva: WHO. Retrieved from http://www.who.int/news-room/ fact-sheets/detail/pesticide-residues-in-food

Xijun, L., Kunsheng, Z., Qingfeng, L., Xu, Z., \& Shuyi, Z. (2012). The effects of electrolysis at room temperature on retrogradation of sweet potato starch. International Journal of Biological Macromolecules, 50(1), 38-42. http://dx.doi.org/10.1016/j.ijbiomac.2011.09.022. PMid:22008104. 